\title{
Indonesia Foreign Policy Update: Rough Waves Ahead in the Indo- Pacific
}

\author{
I Gusti Bagus Dharma Agastia \\ School of International Relations, President University \\ agastia@president.ac.id
}

In the 2018 Shangri-La Dialogue, the term "Indo-Pacific" has been reinvigorated, prompting states within the scope of the geopolitical construct to reassess and recalibrate their foreign policy outlooks and approaches. The three major powersChina, India, and the United States-along with Japan and Australia have proposed new outlooks on the region.

Situated in a highly dynamic region at the crossroads of the Pacific and Indian Ocean, Indonesia's foreign policy has long been influenced by both international and domestic factors. In light of these changes, we firstly look at the development of Indonesia's external environment. This discussion centres on the dynamics of major power in the Indo-Pacific specifically their outlooks, approaches, and interests in the region. Next, we examine Indonesia's domestic dynamics, particularly those related to the progress of the development of the Global Maritime Fulcrum (GMF). In this section, we will discuss the process of naval modernization and an update of national political dynamics as the 2019 Presidential Elections loom closer. Finally, we examine the progress of Indonesia's bilateral and multilateral cooperation.

\section{External environment development over the last year}

Over the last year, the term "Indo-Pacific" has become a buzzword in Asia-Pacific discourse. In some countries, it has even been used as a replacement for the concept of "Asia-Pacific". For example, the United States recently changed their "Pacific Command" to "Indo-Pacific Command". The term remains a contested concept, but it generally refers to a new geopolitical construct that encompasses countries located in maritime Asia, in the Indian and Pacific Ocean. Some have argued that the term alludes to an acknowledgement of increased Indian influence in the region, while others have criticised the concept as a means of excluding China (Medcalf, 2014; Pang, 2014). Note that it is beyond the scope of this paper to address the finer ontological and epistemological elements of the Indo-Pacific debate. As a geopolitical construct, the term "Indo-Pacific" has indeed been perceived as having importance in great- and middle-power foreign policy discourse. Each state has their respective interpretation of the Indo-Pacific and these perceptions shape their preferred foreign policy approaches to the region. 


\section{China: Belt and Road in the Indo-Pacific}

China's long-term Indo-Pacific strategy has been described as "hardening the hard and softening the soft." This can be interpreted as a two-pronged, "carrot and stick" approach with an emphasis on securing Chinese political and economic interests in the Indo-Pacific (Boon, 2016). These interests are reflected in the long-term geopolitical vision of the Belt and Road Initiative (BRI) that was launched in 2013.

As part of the BRI scheme, China has established partnerships in the region. The first foreign Chinese military base in Djibouti began operations in 2017, adding to the roster of influential actors in the Bab-el-Mandab Strait. Close to India, China has sought to acquire usage rights of Gwadar and Hambantota ports in Pakistan and Sri Lanka respectively. These ports are expected to form China's Indo-Pacific economic linkages with possibilities for further naval development (Agastia, 2018).

In Southeast Asia, the South China Sea remains a contentious issue for the claimants. Despite the 2016 Permanent Court of Arbitration ruling in favour of the Philippines, China has continued its forays in the South China Sea. Recent satellite imagery compiled by the Asian Maritime Transparency Initiative shows Chinese installations in the disputed waters being increasingly equipped. In May, the People's Liberation Army stationed its first long-range bomber in an installation at Woody Island (part of the Paracel Islands group). More bombers are expected to be stationed across the year. It is predicted that once China equips their major installations in the South China Sea, the bombers will be able to operate (Asia Maritime Transparency Initiative, 18 May 2018).

\section{United States: a renewed commitment?}

Barrack Obama's previous Asia policy was termed the "Asia pivot" or "Rebalance to Asia". President Donald Trump, however, has started using the term "IndoPacific" to describe U.S. foreign policy in Asia. In his speech at the 2017 APEC Summit in Vietnam, President Trump proposed to a "renewed partnership" with "all the nations of the Indo-Pacific" (White House, 10 November 2017). This was later followed up by Secretary of State Mike Pompeo's remarks in the Indo-Pacific Business Forum in July 2018, in which Pompeo articulated what a "free and open" Indo-Pacific would look like. "Free" refers to the ability of nations to protect themselves from coercion; while "open" refers to "open access to seas and airways" (U.S. Department of State, 30 July 2018). Further evidence of a potential U.S. renewed commitment to the Indo-Pacific can be found in the unclassified summary of the 2018 National Defense Strategy. It designates China as a country that "seeks Indo-Pacific regional hegemony". As a response, the U.S. seeks to "expand Indo-Pacific alliances and partnerships" in a bid to create a free and open Indo-Pacific (U.S. Department of Defense, 2018). 
While the turn towards the Indo-Pacific hints towards a renewed commitment to their Asian partners, a more robust and coherent strategy remains to be seen. What is clear is that the U.S. is taking a competitive stance towards China and Russia, which are designated as "revisionist" powers.

\section{Japan: implementing the "confluence of two seas"}

Japan's interest in the Indo-Pacific was first reflected in Shinzo Abe's "Confluence of Two Seas" speech in 2007. In the speech presented at the Indian Parliament, Abe highlighted a "broader Asia". This would later be present in Japan's announcement of the "Free and Open Indo-Pacific Strategy" in 2016. In a joint statement issued by Shinzo Abe and Narendra Modi, emphasis was put on "deep civilizational links" between the two countries, along with a "free and open IndoPacific" as an area of shared interest (India Ministry of External Affairs, 11 November 2016).

\section{Indonesia's Indo-Pacific foreign policy:}

Indonesian foreign policy has always hinged on two sacrosanct principles: "free and active" (bebas aktif). These two principles form the foundation of Indonesia's Indo-Pacific concept.

Since January 2018, the Widodo administration has been active in developing Indonesia's own interpretation of the Indo-Pacific. In Foreign Minister Retno Marsudi's annual speech, she highlighted Indonesia's interest in an "ecosystem of peace, stability, and prosperity" in the Indo-Pacific. Furthermore, Indonesia sought to achieve these interests by cooperating with ASEAN, developing confidence-building measures, and using a "building blocks" approach in creating a regional architecture in the Indo-Pacific. In a similar tone to Japan and the United States, Indonesia's Indo-Pacific concept also employs the terms "free" and "open". However, Retno Marsudi's speech also included additional adjectives, namely "inclusive" and "comprehensive" (Indonesia Ministry of Foreign Affairs, 9 January 2018).

The speech suggests Indonesia's concept of the Indo-Pacific will be centered more on leveraging Indonesia and ASEAN's centrality as a means to increase bilateral and multilateral cooperation among countries in the Indo-Pacific. In this case, Indonesia will use ASEAN as a "fulcrum of connectivity" and "fulcrum of norm setting". The first term refers to physical connectivity, namely the ASEAN Connectivity Master Plan, which envisions a complex network of physical infrastructure that will connect continental and maritime ASEAN. The second term refers to ASEAN's role as a norm diffuser. By using the East Asia Summit (an ASEAN-led multilateral initiative), Indonesia seeks to build the Indo-Pacific in ASEAN's image (Pramono, 2018).

The speech further suggests Indonesia wants a "best of both worlds" approach to the Indo-Pacific, where no country is excluded from the geopolitical construct. This 
can be inferred from the four adjectives Indonesia attaches to the Indo-Pacific, namely "free", "open", "comprehensive", and "inclusive". The U.S. concept of the Indo-Pacific, for example, explicitly excludes China from the geopolitical construct. However, Indonesia does not seek do alienate any potential dialogue partners from the region. To this end, Indonesia seeks to strengthen existing multilateral and bilateral arrangements. At the same time, Indonesia would also need to accelerate its own domestic developments under the Global Maritime Fulcrum (GMF).

\section{Indonesia's domestic conditions}

The Global Maritime Fulcrum was first unveiled by Joko Widodo in 2014. It represents Joko Widodo's vision of Indonesia becoming a regional maritime power in the Indo-Pacific. It became enshrined in a policy document known as the "Indonesia Ocean Policy" in 2017, which outlines seven pillars: marine and human resources development; maritime security, law enforcement, and safety at sea; ocean governance and institutions; maritime economy development; sea space management and marine protection; maritime culture; and maritime diplomacy. This section discusses the development of the strategic and political aspects of the GMF. In the strategic aspect, this section will examine current trends in Indonesia's defense development; whereas in the political aspect, this section examines Indonesia's bilateral and multilateral ventures.

Naval modernization: too little, too late?

In a bid to become a regional maritime power, Joko Widodo pledged to increase the overall military expenditure by 1.5 percent of GDP over the next five years in 2014. Four years into his administration, Indonesia's military expenditure has yet to reach 1 percent of GDP. In 2017, Indonesia's defense budget was USD 8.1 billion; in 2018, the projected amount is closer to IDR 107.7 trillion or USD 7.3 billion (not adjusted for inflation). Despite this, the Ministry of Defense retains the largest portion of the 2018 budget (see Figure 1). 
10 Kementerian dengan Anggaran Terbesar dalam APBN 2018

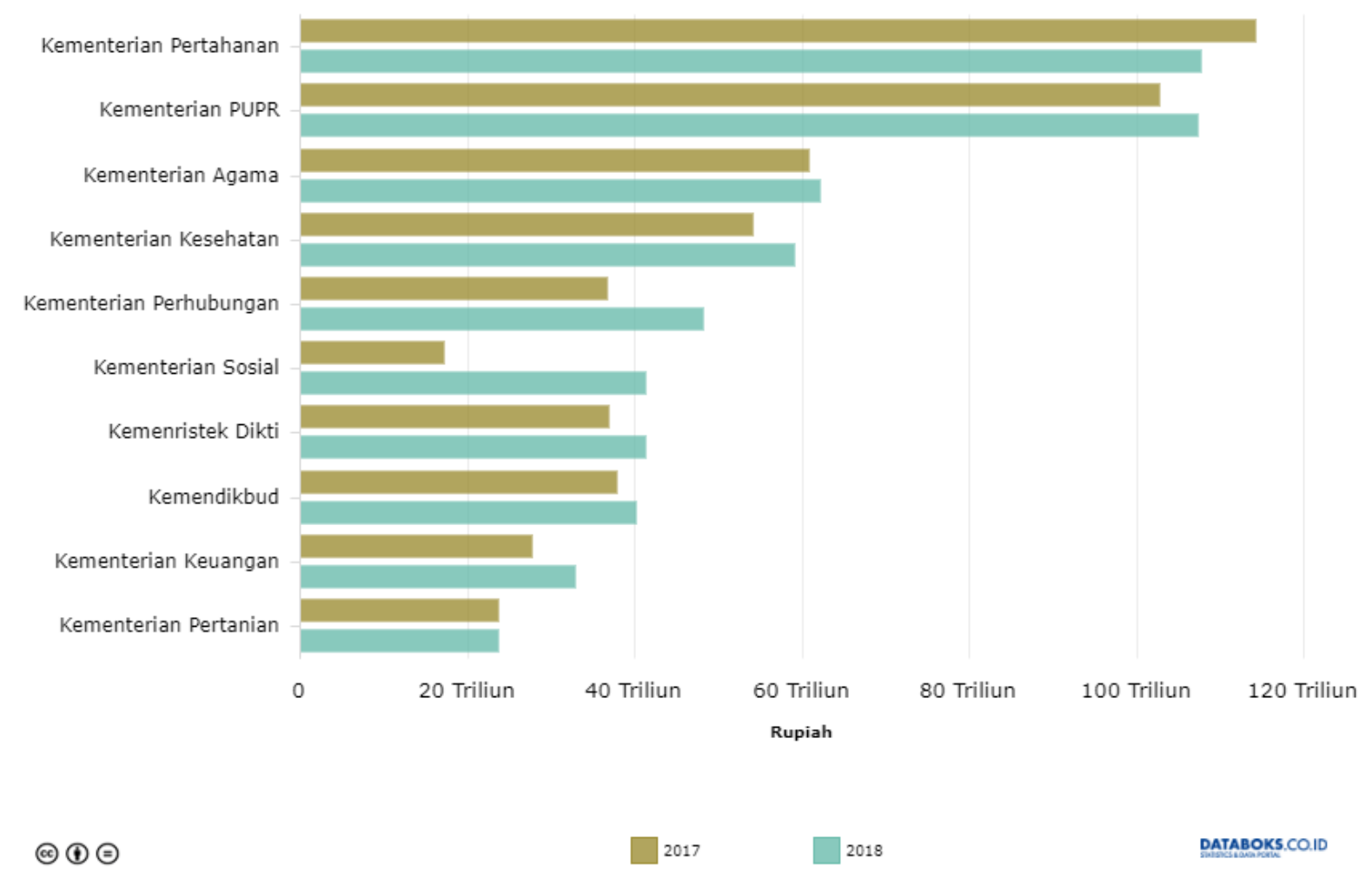

Figure 1 The allocation of the 2018 budget across select ministries (Katadata, 7 February 2018).

This could potentially hamper existing acquisition plans outlined in the Minimum Essential Force guidelines. Furthermore, the Army continues to take a lion's share of the budget to sustain the Territorial Commands -military installations and command outposts-across the archipelago. Amidst these budgetary constraints, the Indonesian Navy welcomed two new Chang Bogo-class submarines (with a third one still in progress) and two new Sigma-class corvettes. However, considering the rapidly aging fleet, Indonesia's naval modernization remains too little and unlikely to reach the targets set out in the Minimum Essential Force guidelines.

Indonesia's commitment to building its maritime defenses can be seen in the recent upgrade of Natuna naval base and plans to build two additional military bases in the outermost islands. The Natuna military base, located in the Riau Islands near the disputed South China Sea, has recently been upgraded to support tri-service joint operations. This upgrade is a concrete response to China's territorial claim of the waters surrounding Natuna (Cochrane, 10 September 2017). Additionally, the military also has plans of constructing a new base on Morotai Island. Located in North Maluku and 600 kilometers southeast of Mindanao, the base is expected to function as a first line of defense against violent extremist groups operating in Mindanao and its surrounding waters (de Haan, 9 July 2017). 
In terms of defense structure, there have been plans to restructure the Territorial Commands and integrate them into joint regional defense commands known as Kogabwilhan (Komando Gabungan Wilayah Pertahanan) which would theoretically be able to provide quicker responses to security threats. Discussions, however, have stalled since 2015 and currently, there is little to suggest it will be implemented soon. Additionally, in May 2018, the Navy established its third fleet command, adding to the existing two fleet commands stationed in Jakarta and Surabaya respectively. The third fleet command, or simply known as "Fleet Command III", is stationed in Sorong, West Papua (Erdianto, 11 May 2018). This would provide the Navy with a better-equipped base of operations in east Indonesian waters, allowing them to conduct traditional and non-traditional maritime security operations in the Arafura Sea.

\section{Indonesia's foreign politics: with or without ASEAN?}

Multilateralism and bilateralism remain two essential practices in Indonesian foreign relations and will likely be further emphasized due to the dynamics in the Indo-Pacific region. Much of Indonesia's foreign relations throughout the year have been addressed at responding to changes in the Indo-Pacific region. Two important countries that are involved include India and China as the two major players in the Indo-Pacific.

Joko Widodo has been busy courting countries of the Indo-Pacific. In late May 2018, Narendra Modi made his first trip to Indonesia. During the visit, Modi and Widodo pledged to increase Indonesia and India's strategic partnership. A major result of the meeting was an agreement to co-develop a deep-sea port in Sabang Island, the westernmost island which marks Indonesia's zero-kilometer point (Panda, 17 July 2018). The island is close to the Andaman and Nicobar Islands where India maintains its Andaman and Nicobar Command. A month after the meeting, the Indian Navy conducted a goodwill visit. While the finer details of the arrangement are still being discussed by both governments, this indicates India will continue to be an important strategic partner for Indonesia.

At the same time, Indonesia will also need to manage to not upset its existing relations with China. Though Indonesia is not officially involved in the South China Sea disputes, there have been tensions with China regarding the status of the waters surrounding the Natuna Islands. However, both countries have expressed the need for more cordial economic relations. This is partly due to Joko Widodo's infrastructure building drive that is partially reliant on Chinese investment in Indonesia (The Straits Times, 9 February 2018). In Indonesia's Indo-Pacific concept, China will likely be viewed as a partner that should not be excluded.

Among the many multilateral initiatives in which Indonesia is a member, ASEAN is likely to remain as a central cornerstone in Indonesia's foreign policy. This has been increasingly emphasized in Indonesia's Indo-Pacific concept, which puts ASEAN as a "double fulcrum" for Indonesia to leverage its geographic centrality 
(Pramono, 2018). However, due to the diversity in the Indo-Pacific, there is still a long way to go before any form of robust regional architecture can be constructed. Indonesia has indeed strived to create a more inclusive region, as shown during Indonesia's chairmanship of the Indian Ocean Rim Association (IORA); however, if Indonesia were to fully implement its Indo-Pacific concept, Indonesia would need to also put in the effort to improve ASEAN's institutional centrality so that it can become an important "double fulcrum".

\section{Conclusion: rough waves ahead}

There are three key points that characterize Indonesia's security and foreign policy so far.

Firstly, there is an increased interest in the dynamics of the Indo-Pacific. This has mostly been influenced by a renewed discussion on the concept of the Indo-Pacific as a geopolitical construct by great powers, namely the United States and China. As a country situated in the middle of the Indo-Pacific, Indonesia has also proposed their own concept of the Indo-Pacific that further accentuates Indonesia's middle position or "pragmatic equidistance" (Laksmana, 2017).

Secondly, Indonesia's security policy has shown a slight shift from a land-based towards a sea-based outlook. This is indicated by increased attention to naval modernization and improvement of maritime infrastructure. However, the government would need to continuously allocate a larger portion of the defence budget towards these ventures.

Thirdly, Indonesia will continue to pursue a mix of bilateralism and multilateralism in its Indo-Pacific foreign policy. This flexibility is perhaps the only pragmatic solution for Indonesia to reconcile its Indo-Pacific concept with other concepts proposed by the other great powers. In terms of multilateralism, ASEAN centrality seems to be a defining characteristic of Indonesia's approach. The challenge would be how Indonesia expects to leverage ASEAN's centrality in approaching foreign relations.

Overall, there are rough waves ahead for Indonesia's Indo-Pacific policy. Whether Indonesia can face those waves depend on its capability to continue with internal improvement and to choose its partners. 


\section{References}

Agastia, I. G. B. D. (2018, 27 July 2018). Race for the Indo-Pacific: implications for us. The Jakarta Post.

Asia Maritime Transparency Initiative. (18 May 2018). China lands first bomber on South China Sea island. Retrieved 16 August, 2018 from https://amti.csis.org/china-lands-first-bomber-south-china-sea-island/.

Boon, H. T. (2016). Hardening the Hard, Softening the Soft: Assertiveness and China's Regional Strategy. Journal of Strategic Studies, 40(5), pp. 639-662.

Cochrane, J. (10 September 2017). Indonesia, Long on Sidelines, Starts to Confront China's Territorial Claims. Retrieved 21 August, 2018 from https://www.nytimes.com/2017/09/10/world/asia/indonesia-south-chinasea-military-buildup.html.

de Haan, J. (9 July 2017). Indonesia to expand naval presence near Mindanao. Retrieved 21 August, 2018 from https://navalinstitute.com.au/indonesiato-expand-naval-presence-near-mindanao/.

Erdianto, K. (11 May 2018). Panglima TNI Resmikan Empat Satuan Baru di Wilayah Timur [TNI Commander Inaugurates Four New Units in Eastern Indonesia]. Retrieved 21 August, 2018 from https://nasional.kompas.com/read/2018/05/11/19030961/panglima-tniresmikan-empat-satuan-baru-di-wilayah-timur.

India Ministry of External Affairs. (11 November 2016). India-Japan Joint Statement during the visit of Prime Minister to Japan. Retrieved 16 August, 2018 from http://mea.gov.in/bilateraldocuments.htm?dtl/27599/IndiaJapan+Joint+Statement+during+the+visi t+of+Prime+Minister+to+Japan.

Indonesia Ministry of Foreign Affairs. (9 January 2018). 2018 Annual Press Statement of the Minister for Foreign Affairs of the Republic of Indonesia H.E. Retno L.P. Marsudi

Katadata. (7 February 2018). APBN 2018: Kementerian Pertahanan Masih Menjadi Prioritas [2018 National Budget: Ministry of Defense Still a Priority]. $\begin{array}{llll}\text { Retrieved } 21 \quad \text { August, } & 2018 \text { from }\end{array}$ https://databoks.katadata.co.id/datapublish/2018/02/07/apbn-2018kementerian-pertahanan-masih-menjadi-prioritas.

Laksmana, E. (2017). Pragmatic Equidistance: How Indonesia Manages its Great Power Relations. In D. B. H. Denoon (Ed.), China, the United States, and the Future of Southeast Asia (pp. 113-135). New York: New York University Press. 
Medcalf, R. (2014). In defence of the Indo-Pacific: Australia's new strategic map. Australian Journal of International Affairs, 68(4), pp. 470-483.

Panda, A. (17 July 2018). India Makes Moves at Indonesia's Strategic Sabang Port. Retrieved 21 August, 2018 from https://thediplomat.com/2018/07/indiamakes-moves-at-indonesias-strategic-sabang-port/.

Pang, C. (2014). The 'Indo-Pacific' and geopolitical anxieties about China's rise in the Asian regional order. Australian Journal of International Affairs, 68(4), pp. 453-469.

Pramono, S. (2018) Indonesia's perspective for an ASEAN outlook on Indo-Pacific: Towards a peaceful, prosperous, and inclusive region - A developing concept. Paper presented at the Seminar on ASEAN Centrality within IndoPacific, Jakarta.

The Straits Times. (9 February 2018). China wants closer ties with Indonesia, says Premier Li Keqiang. Retrieved 21 August, 2018 from https://www.straitstimes.com/asia/se-asia/china-wants-closer-ties-withindonesia-says-li.

U.S. Department of Defense. (2018). Summary of the 2018 National Defense Strategy of the United States of America: Sharpening the American Military's Competitive Edge. Department of Defense.

U.S. Department of State. (30 July 2018). Remarks on "America's Indo-Pacific Economic Vision". Retrieved 16 August, 2018 from https://www.state.gov/secretary/remarks/2018/07/284722.htm.

White House. (10 November 2017). Remarks by President Trump at APEC CEO Summit, Da Nang, Vietnam. Retrieved 16 August, 2018 from https://www.whitehouse.gov/briefings-statements/remarks-presidenttrump-apec-ceo-summit-da-nang-vietnam/. 